\title{
US Senate health care bill draws widespread criticism
}

\author{
n Cite as: CMAJ 2017 July 17;189:E947. doi: 10.1503/cmaj.1095450
}

Posted on cmajnews.com on June 27, 2017.

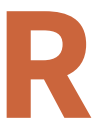
epublican members of the United States Senate have released their version of a health care bill that was narrowly approved by the House of Representatives last month. The Senate bill includes major cuts to Medicaid and will allow states to opt out of some services required by the Affordable Care Act (Obamacare), such as maternity leave, emergency health services and mental health treatment. It will also end the Obamacare mandate that most US citizens have health insurance, but instead would create tax credits to help people buy insurance.

The 142-page bill, released June 22, has been met with a wary reception across the US. Concerns about possible effects of the cuts proposed in the bill include longer waiting times, closure of rural hospitals, cuts to drug-treatment programs, less health coverage for the poor, reduction of taxes for the wealthy, higher insurance premiums for older Americans, and reduced access to women's health services because of slashed funding for Planned Parenthood.

Majority Leader Mitch McConnell said he wants the Senate to vote on the bill this week, but senators from the both Democratic and Republican parties have urged for a delay. A push to vote before the July 4 Senate recess would be unwise, some have suggested, as each state needs more time to evaluate the bill. "Let's have the integrity to show the American people what it is, show them the truth," stated Republican Senator Ron Johnson, who added that there was no need to "rush this process."

Democratic Senator Bernie Sanders embarked on a "Don't Take Our Health Care" tour June 24 and 25 across several states in response to the Senate bill. At one rally, he said that Americans should not have to choose between sending their

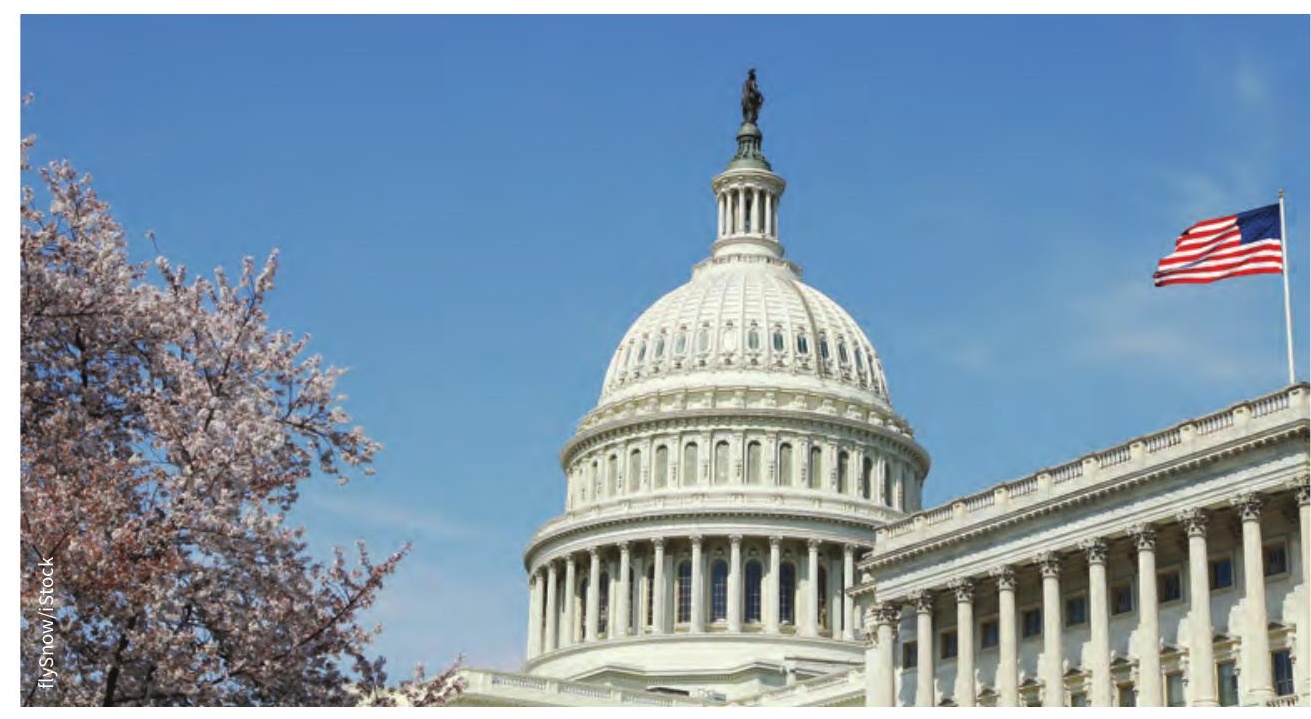

The US Senate's health care bill could leave 22 million more Americans uninsured by 2026, according to a report.

kids to college or their parents to longterm care facilities. "At a time when so many people are hurting, this legislation will cause devastating pain to millions of American families," stated Sanders, who called the Senate bill "the most antiworking-class legislation" in US history.

If the bill does go to vote this week, it may fail for lack of support by Republicans. Several high-profile members of the party, including Ted Cruz and Rand Paul, have come out in opposition to the bill. Another potential problem is the analysis of the bill released by the Congressional Budget Office. That report estimated that 22 million more Americans would become uninsured by 2026 under the new bill, a figure that stands to undermine support for the legislation.

However, White House Senior Advisor Kellyanne Conway defended the bill, claiming it doesn't cut Medicaid. The program had been expanded too much by former President Barack Obama, according to
Conway, and the new bill would bring the program back to its "original moorings."

"Obamacare took Medicaid, which was designed to help the poor, the needy, the elderly, the sick, the disabled, also children, and pregnant women, it took it and it went way above the poverty line and opened it up to many able-bodied Americans who should probably find other should at least see if there are other options for them," stated Conway. "If they're able-bodied and they want to work, then they'll have employer-sponsored benefits like you and I do."

A commentator in Forbes also came to the bill's defence, suggesting it would bring real reform to Medicaid, which he described as a "dysfunctional government-run health care program for the poor whose enrollees have no better health outcomes than the uninsured."

Roger Collier, CMAJ 